\title{
DO ADULT ENGLISH LANGUAGE LEARNERS AND THEIR TEACHERS HAVE SIMILAR APPROACHES TO SUCCESS?
}

Ayse Taskiran', Belgin Aydin ${ }^{2}$

\author{
${ }^{1}$ Anadolu University, Turkey, aysetaskiran@anadolu.edu.tr \\ ${ }^{凶 2}$ Eğitimi Faluktesi Yabancı Diller Bölümü, Anadolu Üniversitesi, Turkey, baydin@anadolu.edu.tr
}

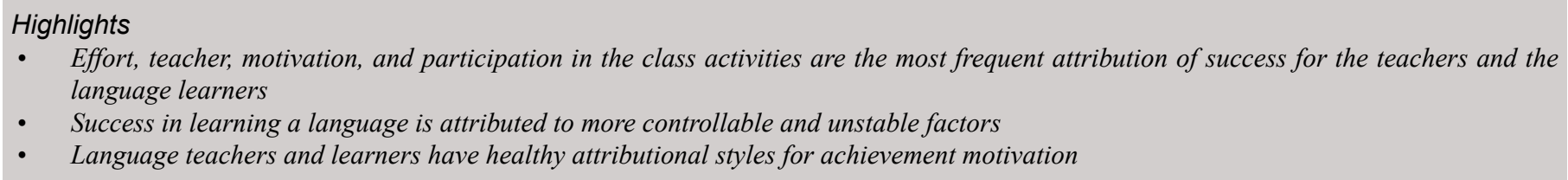

\begin{abstract}
This study explores the similarities and differences between adult language learners' and their teachers' attributions of perceived success and failure in learning English as a foreign language in an intensive program. It examines attributions along with three dimensions: locus of causality, stability and controllability. 319 students and 81 teachers responded to a self-administered questionnaire and reported more attributions for failure than for success. The most frequent attributions both groups stated were effort, teacher, motivation, and participation. Causal dimensionality patterns of success and failureoriented students did not show much differences. They both had significantly more controllable and unstable attributions. Teachers' dimensionality patterns did not differ from that of the students except for locus of control dimension. Causal dimensionality of both teachers and students seemed to be healthy attributional styles according to Weiner's attributional model of achievement motivation.
\end{abstract}

\section{Keywords}

Attribution, causal dimensions, foreign language learning, learners and teachers, success
Article type

Full research paper

Article history

Received: November 8, 2017

Received in revised form: December 12, 2017

Accepted: January 8, 2018

Available on-line: March 30, 2018

Taskiran A., Aydin B. (2018) "Do Adult English Language Learners and Their Teachers Have Similar Approaches to Success?", Journal on Efficiency and Responsibility in Education and Science, Vol. 11, No. 1, pp. 1-8, online ISSN 1803-1617, printed ISSN 2336-2375, doi: 10.7160/eriesj.2018.110101.

\section{Introduction}

Academic success in foreign language education embodies a complex nature dominated by perceptions of learners and teachers. What makes some learners more successful than the others is not merely associated with the quality of instruction or the materials, but with factors ascribed to perceived success and failure by learners and their teachers. Learning more about how learners make sense of their own learning and how teachers perceive their students' performance can shed light on effective teaching and learning. Educational psychologists have long been concerned about the individuals' beliefs about causes of their performance outcomes and how these beliefs shape their expectancies and future behavior (e.g. Killen, 1994; Watkins, 1985; Zeegers, 2004). It has been revealed that people attribute an infinite number of causes to their perceived successes and failures and that these personal contributions influence their subsequent actions. These attributions also create different affective and emotional reactions (Weiner, 1986; Williams, Burden and Al-Baharna, 2001). Particularly, attributions, which are defined as the interpretations of the causes of outcomes by individuals (Weiner, 1985), have been identified as the most significant factors influencing individual's persistence, expectancy of future success, motivation, and in return, academic achievement (Brophy, 1998; Pintrich and Schunk, 1996; Weiner, 2000).

Bernard Weiner, who has made the greatest contribution to attribution theory in achievement contexts, (Pintrich and Schunk, 1996) has developed three separate dimensions: locus of causality (internal vs. external), stability (stable vs. unstable), and controllability (controllable vs. uncontrollable) (Stipek, 1988). According to attribution theory, no matter what causes learners attribute their success or failure, all can be categorized along these three dimensions.
The theory also suggests that some causal attributional styles contribute to constructive achievement-related behavior (adaptive attributions) while some others lead to destructive achievement-related behavior (maladaptive attributions) (Stipek, 1988; Weiner, 1985). Attributing success to internal/ stable/controllable factors is assumed to be healthy, whereas attributing failure to external/stable/uncontrollable factors is considered to be unhealthy.

Since causal dimensionality patterns play an important role in understanding the attributional styles (Dresel, Schober and Ziegler, 2005; Weiner, 1985, 1986), finding out learners' perceptions about the cause of their success and failure in learning another language is important in the motivation and academic achievement of the learners. Then, it would be possible to suggest various ways in order to alter any possible maladaptive attributions and strengthen the adaptive ones. Furthermore, mapping learners' perceptions with those of their teachers will also help to facilitate the effectiveness of language learning environment by identifying any mismatches and solving possible future problems.

\section{Review of the Literature}

There is a growing interest in attributions in the field of language learner motivation. A considerable number of studies have focused on student attributions (Gobel et al., 2011; Tulu, 2013; Williams et al., 2001; Williamset al., 2004) and concluded that high achievers attributing success to ability and low achievers attributing failure to lack of ability (O'sullivan and Howe, 1996). Findings revealed more attribution categories for success, most frequent ones being strategy use, ability, task, teacher, and interest (Williams et al., 2004). Family support, teacher support, exposure to the language were also listed as the 
causes of success, whereas inadequate teaching methods, lack of family and teacher support, and poor comprehension as the causes of failure (Gobel, et al., 2011; Williams et al., 2001).

Effort was cited to be the most frequent cause for both success and failure situations (Dong, Stupnisky and Berry, 2013; Williams et al., 2004). Research focusing on the relation between attributions and achievement (Pishghadam and Zabihi, 2011) cited that effort more than ability regarded as an important factor for higher scores in foreign language achievement while luck and mood did for low scores. A strong association between attributions, self-efficacy and test scores were identified showing significant differences between high and low achievers (Hsieh and Schallert, 2008).

Studies also revealed different findings regarding the relationships between attributions and other variables such as gender, proficiency, culture, and age (Hassaskhah and Vahabi, 2010; Little, 1985; McClure et. al., 2011; Tulu, 2013; Vispoel and Austin, 1995). While some studies focusing on gender found no differences between men and women and concluded that they both externalized failure and internalized success regardless of the context (Ciabuca and Lucian, 2014), others concluded that women, rather than men, attributed effort for success and lack of ability for failure (McClure et al., 2011). Similarly, Tulu (2013) found different attribution patterns of female and male EFL students, citing factors such as poor teaching practices, task difficulty and teacher's bad behaviour as a more important cause of failure for male students than for female students. A few studies revealed different attributional patterns for success and failure in different ethnic, religious and cultural groups (Gobel and Mori, 2007; McClure et al., 2011; Williams et al., 2001). For context variable, Thai and Malaysian students scored higher on internal/controllable success outcomes than Japanese students (Gobel et al., 2011). Urban and rural EFL students held different attribution ratings for success and failure with the urban group being more willing to attribute success to their own ability, effort, and study skills than the rural group (Gobel et al., 2013). Lu, Woodcock and Jiang (2014) found no significant differences in attribution patterns between students who learnt through autonomous learning and those who learnt through teacher-centred approach. Examining if attributions are age specific, Hassaskhah and Vahabi (2010) found that children more than adults and teens had higher scores in instability and controllability dimensions. Unlike teens who owed their failure to task difficulty, children ascribed failure to lack of effort.

Attribution studies mostly focused on the perception of students and ignored how teachers perceived their students' success or failure. As mentioned above, attributions have been identified as including both culture and individual specific natures. In countries where the language classroom is the only context in which the target language is used, trying to understand what is happening in these contexts and how the main stakeholders, learners and teachers perceive these gains are even more important.

Despite a large number of attribution studies around the world, not many studies focused on learners learning English as a Foreign Language (EFL) in the Turkish context. Studies conducted in the Turkish context, similar to the others in the world, conclude effort, interest, teacher and ability as the most frequent attributions for success and effort, interest, class atmosphere and task difficulty attributions for failure (Erten and Burden, 2014; Şahinkarakaş, 2011). Yılmaz (2012) examined Turkish EFL students' and teachers' attributions in reading comprehension and investigated whether student attributions vary across gender, proficiency and teacher opinions. Results revealed significant differences between student and teacher opinions; teachers attributed success to effort or interest and students to feedback and teacher.

Taşkıran and Aydın's (2017) study explored language learners' attributions and causal dimensionality patterns. The study revealed that participants reported more causal attributions for failure than they did for success. Success-oriented students demonstrated significantly more internal, controllable, and relatively more stable attributional styles than failure-oriented students.

This study aims to explore attributions along with casual dimensions for perceived success and failure from the language learners' and their teachers' perspectives. This study set out to answer the following questions:

1. What are adult Turkish students' and their teachers' perceptions of success in learning a foreign language?

2. What do students and teachers attribute their success and failure to?

3. What are the causal dimensionality patterns of students and teachers in success and failure situations?

\section{Materials and Methods}

\section{Participants}

319 adult learners learning English as a foreign language in an intensive language program in Turkey participated in the study. Their ages ranged from 18 to 41 . The language program they were enrolled at followed an integrated skills content-based curriculum for 24 hours each week. Teacher group composed of 81 teachers of English with varying experience years. All participants gave informed consent before answering the questionnaire.

\section{Instrument}

A questionnaire in which the participants were asked to state their attributions to their perceived achievements was used to collect the data of the study. As suggested in literature, dimensional styles vary across individuals and may not always match with the perceived dimensional properties of the researchers (Russell, 1982; Stipek, 1988; Weisz and Stipek, 1982; Vallerand and Richer, 1988). It is the underlying cognitive dimension that represents the individual's beliefs about the nature of the attribution that is believed to be the key to the motivating properties of attributions (Martinko, 1995). Therefore, the participants in this study were asked to decide on their individual dimensions of their attributions through Yes/ No questions. The questionnaire consisted of two questions. The first question asked if they perceived themselves successful or not in the language learning process. The second question asked them to state causes of their perceived achievements. They were asked to list at least five causes. Next to each cause, there were three Yes/No questions that aimed to identify perceived dimensionality patterns (locus of causality, stability, controllability). The participants would mark Yes/No columns according to the perceptions of their causes' being internal or external, stable or unstable, controllable or uncontrollable. They were also provided with a sample in order to guide them in indicating the dimensionality patterns (see Appendix A).

Teacher participants answered the same questionnaire with a different instruction. They were instructed to fill in the questionnaire on the basis of their perceptions of their students' achievements. A sample was also provided to the teacher group. The data were collected during subjects' normal teaching hours. 


\section{Data Analysis Procedures}

Constant Comparison Method (Glaser, 1992) was used for analyzing the data. In order to ensure inter-rater reliability, two researchers analyzed the data independently. First, the answers were divided into two groups categorizing success-oriented and failure-oriented groups. The frequencies of perception of success in both groups were analyzed with chi-square analysis by using crosstabs. The researchers numbered each questionnaire and each attribution. After individual labelling of the causes, researchers came together to compare their labels and to find out any mismatches in their analysis. The data were re-analyzed continually during the negotiations. The labels were assigned only when both researchers reached an agreement.

After all final labels were assigned, they were tabulated with frequency percentages for both success and failure situations. Frequency percentages of attributions for both success- and failure-oriented student and teacher groups were compared. Since each group might have different labels that cannot be compared with the others statistically, all comparisons were done descriptively. Then, a total number of marks for Yes/No questions for causal dimensionality was calculated. In order to analyze the possible differences of causal dimensionality patterns between success-oriented and failure-oriented student and teacher groups, chi-square analysis was conducted by using the total number of marks given for each dimension.

\section{Results}

\section{Perception of Success}

Results revealed higher perception of failure than success both for learners and their teachers. $43 \%$ of Turkish learners perceived themselves successful while $57 \%$ of them felt unsuccessful in learning a foreign language. Perception of failure among teachers was much higher than their students; while only $19 \%$ of the teachers found their learners successful, $81 \%$ of them considered them unsuccessful (see Table 1: Perception of success).

\begin{tabular}{|c|c|c|c|c|}
\hline & \multicolumn{2}{|c|}{ Students } & \multicolumn{2}{c|}{ Teachers } \\
\hline Perception & $\mathrm{f}$ & $\%$ & $\mathrm{f}$ & $\%$ \\
\hline SO $^{*}$ & 138 & 43 & 15 & 18 \\
\hline FO & 181 & $\mathbf{5 7}^{* *}$ & 66 & $\mathbf{8 1}$ \\
\hline Total & 319 & 100 & 81 & 100 \\
\hline
\end{tabular}

* SO=Success-oriented, FO=Failure-oriented

** Higher percentages are shown in boldface.

Table 1: Perception of success

As can be assumed, this resulted in significant differences between students' and their teachers' perceptions of success $\left(\chi^{2}=17.34, \mathrm{Df}=1, \mathrm{p}=0.000\right)$ (see Table 2: Differences in the perception of success between teacher and student groups).

\begin{tabular}{|l|l|c|c|c|}
\hline \multirow{2}{*}{ Groups } & & \multicolumn{2}{|c|}{ Perception } & \multirow{2}{*}{ Total } \\
\cline { 3 - 4 } & & Success & Failure & \\
\hline \multirow{2}{*}{ Student } & Count & 138 & 181 & 319 \\
\cline { 2 - 4 } & Expected Count & 188.1 & 197.9 & 319.0 \\
\hline \multirow{2}{*}{ Teacher } & Count & 15 & 66 & 81 \\
\cline { 2 - 4 } & Expected Count & 31.9 & 49.1 & 81.0 \\
\hline \multirow{2}{*}{ Total } & Count & 153 & 247 & 400 \\
\cline { 2 - 4 } & Expected Count & 153.0 & 247.0 & 400.0 \\
\hline \multicolumn{2}{|l|}{$\chi^{2}=17.34, \mathrm{Df}=1, \mathrm{p}=0.000$} \\
\hline
\end{tabular}

Table 2: Differences in the perception of success between teacher and student groups

\section{Attributions of Failure and Success}

Language learners, like their teachers, seemed to have more to say about the causes of failure than success (see Table 3:
Distribution of causes for success and failure between groups). Students stated $464(41.9 \%)$ causes for their success and 644 $(58.1 \%)$ causes for their failure in language learning.

\begin{tabular}{|c|c|c|c|c|}
\hline & \multicolumn{2}{|c|}{ Students } & \multicolumn{2}{c|}{ Teachers } \\
\hline Perception & $\mathrm{f}$ & $\%$ & $\mathrm{f}$ & $\%$ \\
\hline SO $^{*}$ & 464 & 41.9 & 58 & 19 \\
\hline FO & 644 & 58.1 & 257 & 81.6 \\
\hline Total & 1108 & 100 & 315 & 100 \\
\hline
\end{tabular}

Table 3: Distribution of causes for success and failure between groups

These causes were categorized into 17 labels for success (see Figure 1: Most frequent attributions of success-oriented students) and 27 labels for failure situation (see Figure 2: Most frequent attributions of failure-oriented students). Adult learners believed that their effort $(50 \%)$ was the main reason of their success; teacher factor $(19 \%)$, school system $(8 \%)$, participating in the lesson $(5 \%)$ and using the target language in their daily life $(5 \%)$ were among the other main causes stated by the students causing them to be successful language learners.

MOST FREQUENT ATTRIBUTIONS OF SUCCESS-ORIENTED STUDENTS:

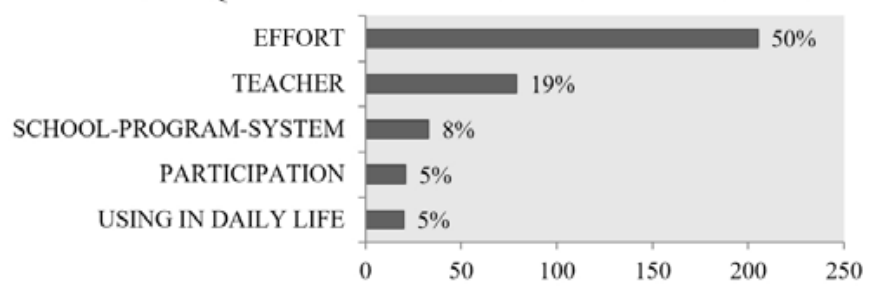

Figure 1: Most frequent attributions of success-oriented students

On the other hand, they perceived that the main reason of their failure was the school-program-system (36\%). Lack of effort (21\%), lack of ability (5\%), lack of motivation (5\%) and the teachers $(3 \%)$ were identified among the other causes leading them to fail.

\section{MOST FREQUENT ATTRIBUTIONS OF FAILURE-ORIENTED STUDENTS}

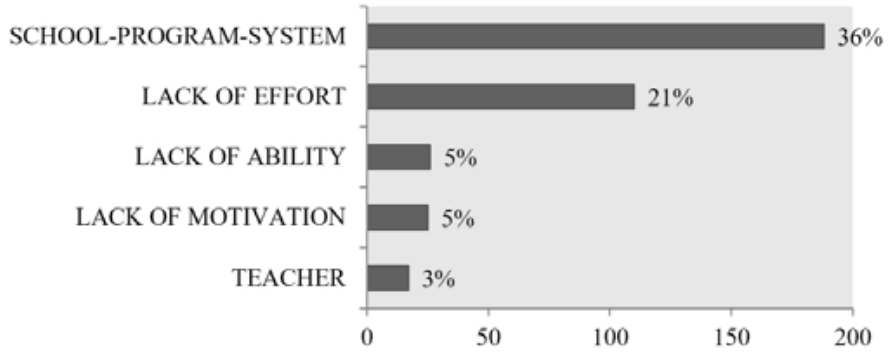

Figure 2: Most frequent attributions of failure-oriented students

Out of teacher attribution data, $58(18.4 \%)$ causes for success and $257(81.6 \%)$ causes for failure were identified. These causes were categorized in 11 labels for success situation (see Figure 3: Most frequent attributions of success-oriented teachers) and 36 labels for failure situation (see Figure 4: Most frequent attributions of failure-oriented teachers). As seen in Figure 3, just like their students, teachers believed that effort (24\%) was the main source of success, which was followed by motivation $(16 \%)$, teacher factor $(12 \%)$, participation $(12 \%)$, and schoolprogram-system $(10 \%)$.

Similar to learners' responses, teachers attributed more causes to failure than they did to success. Not showing enough effort (23\%) was the real cause of the students' failure from the perception of their teachers. Not being motivated (12\%) for learning the foreign language, the system of the program $(11 \%)$, students' not being able to use learning strategies (8\%) and their lack of awareness $(7 \%)$ were listed as the other causes from the teachers' perspective. 
MOST FREQUENT ATTRIBUTIONS OF SUCCESS-ORIENTED TEACHERS

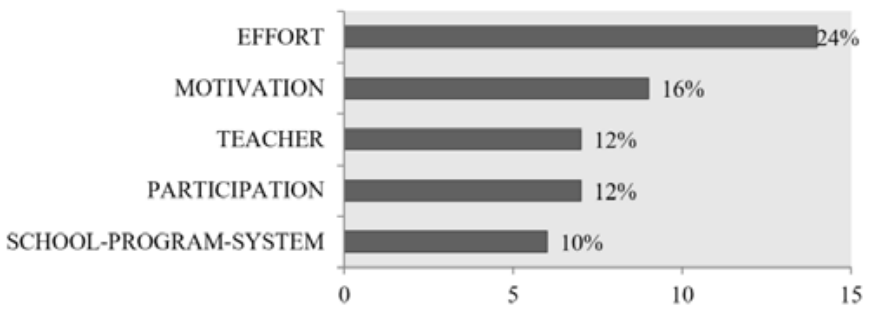

Figure 3: Most frequent attributions of success-oriented teachers

MOST FREQUENT ATTRIBUTIONS OF FAILURE-ORIENTED TEACHERS

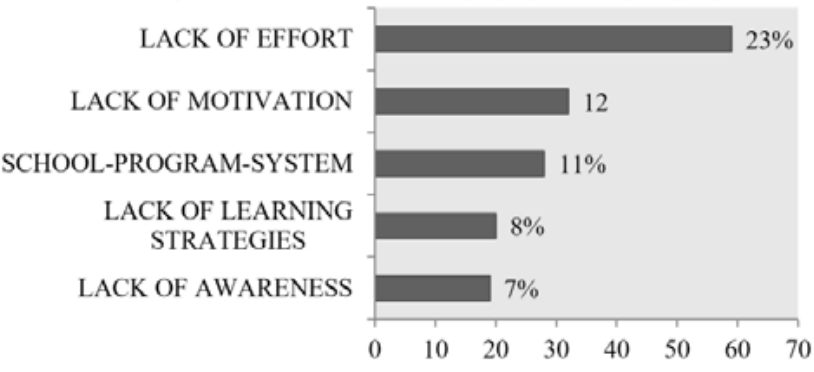

Figure 4: Most frequent attributions of failure-oriented teachers

\section{Causal Dimensionality Patterns}

Causal dimensionality analyses revealed variation in the total number of marks for each dimensional property. That is because some participants did not mark some of the property columns for some of their attributions (see Table 4: Causal dimensionality for the student and teacher groups).

Causal dimensionality results indicated that both successoriented and failure-oriented students ascribed their successes more to unstable and controllable causes, and the results changed for the causes being internal for success-oriented and external for failure-oriented students. Both failure and successoriented teachers' casual dimensionality results yield the same conclusion; causes leading their students' success or failure were internal, unstable, and controllable reasons.

\begin{tabular}{|l|c|c|c|c|c|c|c|c|}
\hline \multirow{2}{*}{} & \multicolumn{4}{|c|}{ Students } & \multicolumn{4}{c|}{ Teachers } \\
\cline { 2 - 10 } & \multicolumn{2}{|c}{ SO } & \multicolumn{2}{c|}{ FO } & \multicolumn{3}{c|}{ SO } & \multicolumn{2}{c|}{ FO } \\
\hline Causal Dimensions & $\mathrm{n}$ & $\%$ & $\mathrm{n}$ & $\%$ & $\mathrm{n}$ & $\%$ & $\mathrm{n}$ & $\%$ \\
\hline Internal & 302 & $\mathbf{7 3 . 6}$ & 232 & 48.2 & 44 & $\mathbf{7 5 . 9}$ & 166 & $\mathbf{6 6 . 4}$ \\
\hline External & 108 & 26.4 & 249 & $\mathbf{5 1 . 8}$ & 14 & 24.1 & 84 & 33.6 \\
\hline Total Marks & 410 & 100 & 481 & 100 & 58 & 100 & 250 & 100 \\
\hline Stable & 147 & 35.6 & 117 & 24 & 15 & 28.3 & 37 & 15.1 \\
\hline Unstable & 265 & $\mathbf{6 4 . 4}$ & 371 & $\mathbf{7 6}$ & 38 & $\mathbf{7 1 . 7}$ & 208 & $\mathbf{8 4 . 9}$ \\
\hline Total Marks & 412 & 100 & 488 & 100 & 53 & 100 & 245 & 100 \\
\hline Controllable & 350 & $\mathbf{8 6}$ & 391 & $\mathbf{7 7 . 4}$ & 46 & $\mathbf{8 2 . 1}$ & 190 & $\mathbf{7 9 . 2}$ \\
\hline Uncontrollable & 45 & 14 & 114 & 22.6 & 10 & 17.9 & 50 & 20.8 \\
\hline Total Marks & 407 & 100 & 505 & 100 & 56 & 100 & 240 & 100 \\
\hline
\end{tabular}

Table 4: Causal dimensionality for the student and teacher groups

Causal dimensionality patterns between success and failureoriented students revealed statistically significant results in terms of locus of causality, stability and controllability. Results revealed that both failure-oriented and success oriented groups had more unstable and controllable attributions. However, for locus of causality dimension, success group had more internal attributions, while failure group's locus of causality dispersed almost evenly (see Table 5: Causal dimensionality patterns between success- and failure-oriented students).

Teacher groups, on the other hand, revealed no significant ( $p>.05)$ difference in terms of locus of causality and controllability dimensions. Both groups had more internal and controllable attributional styles. However, although both groups thought the cause of success and failure were unstable, statistical differences were found in stability dimension $(\mathrm{p}<.05)$ with failure-oriented teachers having considerably more unstable dimensions (see Table 6: Comparison of causal dimensionality between failureand success-oriented teachers).

\begin{tabular}{|c|c|c|c|c|c|c|c|c|c|}
\hline \multirow{2}{*}{$\begin{array}{c}\text { Student } \\
\text { Gr. }\end{array}$} & \multicolumn{3}{|c|}{ Locus of Causality } & \multicolumn{3}{|c|}{ Stability } & \multicolumn{3}{|c|}{ Controllability } \\
\hline & Internal & External & Total & Stable & Unstable & Total & Control. & Uncontrol. & Total \\
\hline SO Count & 302 & 108 & 410 & 147 & 265 & 412 & 350 & 57 & 407 \\
\hline $\begin{array}{c}\text { Expected } \\
\text { count }\end{array}$ & 245.7 & 164.3 & 410.0 & 120.9 & 291.1 & 412.0 & 330.7 & 76.3 & 407.0 \\
\hline FO Count & 232 & 249 & 481 & 117 & 371 & 488 & 391 & 114 & 505 \\
\hline $\begin{array}{l}\text { Expected } \\
\text { count }\end{array}$ & 288.3 & 192.7 & 481.0 & 143.1 & 344.9 & 488.0 & 410.3 & 94.7 & 505.0 \\
\hline $\begin{array}{c}\text { Total } \\
\text { Count }\end{array}$ & 534 & 357 & 891 & 264 & 636 & 900 & 741 & 171 & 912 \\
\hline $\begin{array}{c}\text { Expected } \\
\text { count }\end{array}$ & 534.0 & 357.0 & 891.0 & 264.0 & 636.0 & 900.0 & 741.0 & 171.0 & 912.0 \\
\hline $\begin{array}{c}\text { Signifi- } \\
\text { cance }\end{array}$ & $\chi^{2}=59$ & $\mathrm{f}=1$ & 0.0 & & $\begin{array}{l}14.76, D \\
p=0.000\end{array}$ & & & $\mathrm{Df}=1$ & 001 \\
\hline
\end{tabular}

Table 5: Causal dimensionality patterns between success- and failure-oriented students

\begin{tabular}{|c|c|c|c|c|c|c|c|c|c|}
\hline \multirow{2}{*}{$\begin{array}{c}\text { Student } \\
\text { Gr. }\end{array}$} & \multicolumn{2}{|c|}{ Locus of Causality } & \multicolumn{3}{|c|}{ Stability } & \multicolumn{3}{c|}{ Controllability } \\
\cline { 2 - 11 } & Internal & External & Total & Stable & Unstable & Total & Control. & Uncontrol. & Total \\
\hline SO Count & 44 & 14 & 58 & 15 & 38 & 53 & 46 & 10 & 56 \\
\hline $\begin{array}{c}\text { Expected } \\
\text { count }\end{array}$ & 39.5 & 18.5 & 58 & 9.2 & 43.8 & 53 & 44.6 & 11.4 & 56 \\
\hline FO Count & 166 & 84 & 250 & 37 & 208 & 245 & 190 & 50 & 240 \\
\hline $\begin{array}{c}\text { Expected } \\
\text { count }\end{array}$ & 170.5 & 79.5 & 250 & 42.8 & 202.2 & 245 & 191.4 & 48.6 & 240 \\
\hline $\begin{array}{c}\text { Total } \\
\text { Count }\end{array}$ & 210 & 98 & 308 & 52 & 246 & 298 & 236 & 60 & 296 \\
\hline $\begin{array}{c}\text { Expected } \\
\text { count }\end{array}$ & 210 & 98 & 308 & 52 & 246 & 298 & 236.0 & 60 & 296 \\
\hline $\begin{array}{c}\text { Signifi- } \\
\text { cance }\end{array}$ & $\chi^{2}=1.94, \mathrm{Df}=1, \mathrm{p}=0.163$ & $\chi^{2}=5.27, \mathrm{Df}=1, \mathrm{p}=0.022$ & $\chi^{2}=.25, \mathrm{Df}=1, \mathrm{p}=0.618$ \\
\hline
\end{tabular}

Table 6: Comparison of Causal Dimensionality between Failureand Success-Oriented Teachers

When the results of the students were compared with those of their teachers, no significant difference $(\mathrm{p}>.05)$ was revealed between success-oriented students and teachers across dimensions with both group having considerably more internal, unstable and controllable attributions (see Table 7: Comparison of causal dimensionality between success-oriented teachers and students).

\begin{tabular}{|c|c|c|c|c|c|c|c|c|c|c|}
\hline \multirow{2}{*}{$\begin{array}{c}\text { Student } \\
\text { Gr. }\end{array}$} & \multicolumn{2}{|c|}{ Locus of Causality } & \multicolumn{3}{c|}{ Stability } & \multicolumn{3}{c|}{ Controllability } \\
\cline { 2 - 11 } & Internal & External & Total & Stable & Unstable & Total & Control. & Uncontrol. & Total \\
\hline $\begin{array}{c}* \text { SOS } \\
\text { Count }\end{array}$ & 302 & 108 & 410 & 147 & 265 & 412 & 350 & 57 & 407 \\
\hline $\begin{array}{c}\text { Expected } \\
\text { count }\end{array}$ & 303.1 & 106.9 & 410 & 143.5 & 268.5 & 412 & 348.1 & 58.9 & 407 \\
\hline $\begin{array}{c}* \text { SOT } \\
\text { Count }\end{array}$ & 44 & 14 & 58 & 15 & 38 & 53 & 46 & 10 & 56 \\
\hline $\begin{array}{c}\text { Expected } \\
\text { count }\end{array}$ & 42.9 & 15.1 & 58 & 18.5 & 34.5 & 53 & 47.9 & 8.1 & 56 \\
\hline $\begin{array}{c}\text { Total } \\
\text { Count }\end{array}$ & 346 & 122 & 468 & 162 & 303 & 465 & 396 & 67 & 463 \\
\hline $\begin{array}{c}\text { Expected } \\
\text { count }\end{array}$ & 346 & 122 & 468 & 162 & 303 & 465 & 396 & 67 & 463 \\
\hline $\begin{array}{c}\text { Signifi- } \\
\text { cance }\end{array}$ & $\chi^{2}=.13, \mathrm{Df}=1, \mathrm{p}=0.720$ & $\chi^{2}=1.13, \mathrm{Df}=1, \mathrm{p}=0.289$ & $\chi^{2}=.59, \mathrm{Df}=1, \mathrm{p}=0.442$ \\
\hline
\end{tabular}

*SOT=success-oriented teacher,

**SOS=success-oriented students

Table 7: Comparison of causal dimensionality between successoriented teachers and students

The analyses of causal dimensionality patterns between failure-oriented student and teacher groups, however, revealed significant differences $(p<.05)$ in terms of locus of causality and stability dimensions. Teacher group tended to have more internal attributions for failure, whereas the student group scored almost the same for both internal and external attributions. Similarly, teacher group had considerably more unstable attributions when compared to student group. For controllability dimension no significant difference $(p>.05)$ 
was observed between teacher and student groups with both groups having more controllable attributions (see Table 8: Comparison of causal dimensionality between failureoriented teachers and students).

\begin{tabular}{|c|c|c|c|c|c|c|c|c|c|}
\hline \multirow{2}{*}{$\begin{array}{l}\text { Student } \\
\text { Gr. }\end{array}$} & \multicolumn{3}{|c|}{ Locus of Causality } & \multicolumn{3}{|c|}{ Stability } & \multicolumn{3}{|c|}{ Controllability } \\
\hline & Internal & External & Total & Stable & Unstable & Total & Control. & Uncontrol. & Total \\
\hline $\begin{array}{l}* * \text { FOS } \\
\text { Count }\end{array}$ & 232 & 249 & 481 & 117 & 371 & 488 & 391 & 114 & 505 \\
\hline $\begin{array}{c}\text { Expected } \\
\text { count }\end{array}$ & 261.9 & 219.1 & 481 & 102.5 & 385.5 & 488 & 393.8 & 111.2 & 505 \\
\hline $\begin{array}{l}\text { *FOT } \\
\text { Count }\end{array}$ & 166 & 84 & 250 & 37 & 208 & 245 & 190 & 50 & 240 \\
\hline $\begin{array}{c}\text { Expected } \\
\text { count }\end{array}$ & 136.1 & 113.9 & 250 & 51.5 & 193.5 & 245 & 187.2 & 52.8 & 240 \\
\hline $\begin{array}{c}\text { Total } \\
\text { Count }\end{array}$ & 398 & 333 & 731 & 154 & 579 & 733 & 581 & 164 & 745 \\
\hline $\begin{array}{c}\text { Expected } \\
\text { count }\end{array}$ & 398 & 333 & 731 & 154 & 579 & 733 & 581 & 164 & 745 \\
\hline $\begin{array}{c}\text { Signifi- } \\
\text { cance }\end{array}$ & \multicolumn{3}{|c|}{$\chi^{2}=21.89, \mathrm{Df}=1, \mathrm{p}=0.000$} & \multicolumn{3}{|c|}{$\chi^{2}=7.74, \mathrm{Df}=1, \mathrm{p}=0.005$} & \multicolumn{3}{|c|}{$\chi^{2}=.29, \mathrm{Df}=1, \mathrm{p}=0.592$} \\
\hline
\end{tabular}

Table 8: Comparison of causal dimensionality between failureoriented teachers and students

\section{Discussion}

The aim of the study was to explore perceived success and failure of adult learners learning a foreign language and their teachers as well as to examine their attributions across causal dimensions. Findings indicated that perception of failure was more common for both learner and teacher groups. They both focused on failure more and perceived themselves and their students as unsuccessful language learners. That is, more than half of the adult Turkish students do not believe that they are successful in learning English; their teachers even much more strongly believe that the learners they are teaching are not successful. This is an important result that might have negative consequences in the learning process and their teachers' negative perceptions of their students' success might also affect their learners' perceptions of their own success.

Similarly, attributions stated for failure were more than those stated for success in both teacher and student groups, a finding supported by attribution theory; more why-questions are asked when failures are experienced (Weiner, 1979; Weiner, 2000). Both student and teacher groups attributed almost the same causes for success and failure situations with slight differences in percentages. This result contradicts with the findings of previous research (e.g. Killen, 1994; Zepke, Leach, Butler, 2014). For instance, in Zepke, Leach and Butler's study, which focuses on teacher and student perception about learner engagement, although teachers and students had some similar perceptions, they had more dissimilar perceptions about what engages students.

Effort attribution seems to be among the most frequent attributions in all groups, a finding that is in parallel with the findings of many attribution studies (Graham, 2004; McQuillan, 2000; Niles, 1984; Park and Kim, 1998; Watkins, 1985; Watkins and Regmi, 1993; Williams and Burden, 1999; Williams et al., 2001; Williams et al., 2004). Both teacher and student groups are aware that as long as they put enough effort, they will succeed. While effort appeared at the top of the list for both groups, the percentage of students' attribution almost doubled that of their teachers. Considering the positive correlation between effort and academic success (Pishghadam and Zabihi, 2011), an important implication of the study would be encouraging students to maintain their point of view through more conscious attention of their learning process.

Both students and teachers identified motivation and schoolprogram-system as the other frequent attributions, but for the latter, attribution students scored two times higher than the teachers. While teachers also attributed their students' failure to not being aware of their learning process and not using language-learning strategies efficiently, students believed they did not have ability to learn a foreign language and blamed their teachers for their failures.

The most frequent attributions in this study that is effort, teacher, motivation, and participation are among common attributions cited in other studies (Killen, 1994; Mao, 2003; Pishghadam and Zabihi, 2011; Şahinkarakaş, 2011; Williams et al., 2005). However, although luck and task difficulty are accepted as common attributions in research (Graham, 1991; Graham, 2004; Tse, 2000; Weiner, 1979, 1984; Williams et al., 2004), in Turkish context students do not seem to include those in their attributions in this study. This finding suggests that Turkish students seem to feel they have more control over the causes of their outcomes, as they mainly focus on personal rather than impersonal attributions. Also, ability attribution has been mentioned in low frequencies, which contradicts with attribution research. Similarly, this may indicate that the students in Turkish context do not tend to lose their hope to be successful, as they do not consider the causes that cannot be changed such as faith or ability while reflecting on their outcomes.

Causal dimensionality analyses are also significant and present a clear picture of the causes' subjective meaning to individuals. Those underlying cognitive dimensions give more insights about the motivating properties of causes. Causal dimensionality patterns of success- and failure-oriented students did not show much difference, which contradicts with the findings of similar research on attributions (Chen, 2011; Dong, Stupnisky and Berry, 2013; He and Li, 2010; Hu, Shi and Zhou, 2009; Soric, 2009; Chen and Zhang, 2011). Moreover, those patterns were mostly promising as they fit into the healthy attributional styles. Both success and failure groups had significantly more controllable and unstable attributions. Failure group students still felt having control over their achievement outcomes, which is a promising finding in terms of expectation of future success. If it had been otherwise, they would be more likely to develop low self-esteem, poor motivation and consequently tendency to give up (Brophy, 1998; Lebedina-Manzoni, 2004; Waugh, 2002). In contrast to Chinese context (Lei, 2009), Turkish learners had significantly more internal and controllable attributions, which is accepted as an adaptive attributional style as it signals higher self-efficacy (Schunk and Gunn, 1986; Tremblay and Gardner, 1995). However, success group students consider their achievements as unstable, which shows similarity with another study in Chinese context (Lu, Woodcock and Jiang (2014). This finding should be examined in more detail through individual interviews. There is no doubt that maintaining positive opinion of oneself is important for future expectation of success. Failure group, on the other hand, had slightly more external attributions, which is in parallel with some attribution research (Burden and Al-Baharna, 2001; Chen, 2011; Ushioda, 2001). However, as they tend to believe failure is caused by unstable and controllable factors, they may have positive attitude toward language learning and may develop higher expectancy for future success. This finding might help language teachers who can foster motivation in their classes even if their students are failure-oriented.

Causal dimensionality styles of success- and failureoriented teachers do not show any difference as both groups 
have significantly more internal, unstable and controllable attributions. This also is a promising finding as failure group has as much adaptive attributional style as success group. Moreover, teachers' dimensionality patterns do not differ from that of the students except for locus of control dimension. Both teacher and student groups had more unstable and controllable attributions for success and failure. However, teachers ascribed their students' failure significantly more to internal reasons, while about half of the student group believed their failure was caused by external reasons. Teachers' dimensionality patterns are accepted as healthy attributional styles according to attribution theory. It is claimed that attributing failure to internal / unstable / controllable causes will promise better results for future performance (Weiner, 1985). One implication could be to find ways to transfer this adaptive point of view from teachers to students. As long as teachers assist their learners to look for the causes of their failure within themselves and take more responsibility of their own learning, students can put more effort on school tasks.

\section{Conclusion}

The results of this study reveal that majority of Turkish teachers perceive their students unsuccessful in learning a foreign language. Therefore, as one of the main implications, teachers should be informed about how their perceptions might affect their teaching and how their students might be affected by these negative perceptions. Explicit in-service training might focus on explaining the research results with the various ways of changing teachers' negative perceptions into positive ones. In order to help their students to change their negative perceptions, teachers should change their own perceptions of their students' success, and be encouraged to focus on setting short-term goals for learning and help their learners achieve these goals. Similarly, failure-oriented students can be informed about the negative effects of their orientations and their point of views can be changed away from negative to positive with the help of teachers' contributions. Both groups should be informed that these negative perceptions might cause academic failure which in turn leads to low self-esteem, poor motivation and tendency to give up (Lebedina-Manzoni, 2004; Waugh, 2002). They can be encouraged to understand that previous unpleasant experiences are unstable and they can change for the opposite with their effort.

Moreover, in order to create a mutual understanding on teaching-learning process, it is significant to know how each side describe achievement outcomes and inform each side about their attributions. Negotiations to alter the maladaptive attribution start with being aware of them.

This study allowed students to openly report their attributions and rate causal dimensions for each ascription. In this sense, this study can be regarded as being representative of both student and teacher groups' true attributional profiles. All in all, these findings are limited to an intensive language learning program context so similar studies in other higher education institutions in Turkish context can be conducted to gain more insights about the attribution styles of the learners and the teachers. This will shed light on the plans for teacher in-service training and motivational problems in foreign language learning process.

\section{References}

Brophy, J.E. (1998) Motivating students to learn. New York: McGraw-Hill.

Chen, C. and Zhang, L. (2011) 'Temperament, personality and achievement goals among Chinese adolescent students', Educational Psychology, vol. 31, no. 3, pp. 339-359. https://doi. org/10.1080/01443410.2011.559310

Chen L.-Y. (2011) A study on the attribution orientation of senior high school students in English learning (Master's thesis). Henan Normal University, Xinxiang, China.

Ciabuca, A. and Gheorghe, L., 2014. 'Attribution for success and failure in Romanian context. Theoretical model that accounts for explaining performance', Procedia- Social and Behavioral Sciences, 159, pp. 254-260.

Dong, Y., Stupnisky, R.H. and Berry, J.C. (2013) 'Multiple causal attributions: An investigation of college students learning a foreign language', European journal of psychology of education, vol. 28, no. 4, pp. 1587-1602. https://doi.org/10.1007 /s10212-013-0183-4

Dresel, M., Schober, B., Ziegler, A. (2005) 'Nothing more than dimensions? Evidence for a surplus meaning of specific attributions', The Journal of Educational Research, vol. 99, no. 1, pp. 31-45. https://doi.org/10.3200/JOER.99.1.31-45

Erten, İ.H. and Burden, R.L. (2014) 'The relationship between academic self-concept, attributions, and L2 achievement', System, vol. 42, pp. 391-401. https://doi.org/10.1016/j. system.2014.01.006

Glaser, B.G. (1992) Emergence vs forcing: Basic of grounded theory analysis. Mill Valley, CA: Sociology Press.

Gobel, P. and Mori, S. (2007) 'Success and failure in the EFL classroom: Exploring students' attributional beliefs in language learning', Euro SLA Yearbook, vol. 7, pp. 149-169.

Gobel, P., Mori, S., Thang, S.M., Kan, N. H. and Lee, K.W. (2011) 'The impact of culture on student attributions for performance: A comparative study of three groups of EFL/ESL learners', Journal of Institutional Research (South East Asia) (JIRSEA), vol. 9, no. 1, pp. 27-43.

Gobel, P., Thang, S.M., Sidhu, G.K., Oon, S.I. and Chan, Y.F. (2013) 'Attributions to Success and Failure in English Language Learning: A Comparative Study of Urban and Rural Undergraduates in Malaysia', Asian Social Science, vol. 9, no. 2, pp. 53-62. http://dx.doi.org/10.5539/ass.v9n2p53

Graham, S.J. (1991) 'A review of attribution theory in achievement contexts', Educational Psychology Review. vol. 3, pp. 5-39.

Graham, S.J. (2004) 'Giving up on modern foreign languages? Students' perceptions of learning French', The Modern Language Journal, vol. 88, no. 2, pp. 171- 191. http://dx.doi. org/10.1111/j.0026-7902.2004.00224.x

Hassaskhah, J. and Vahabi, M. (2010) 'An in-depth analysis of the relationship between age and attribution in EFL contexts', Procedia Social and Behavioral Sciences, vol. 5, pp. 2126-2132. http://dx.doi.org/10.1016/j.sbspro.2010.07.425

He H.-Y. and Li F. (2010) 'A study on college students' attribution of English learning', Journal of Hubei University of Economics (Humanities and Social Sciences), vol. 7, no. 7, pp.186-188.

Hsieh, P.H.P., and Schallert, D.L. (2008) 'Implications from self-efficacy and attribution theories for an understanding of undergraduates' motivation in a foreign language course', Contemporary Educational Psychology, vol. 33, pp. 513-532. http://dx.doi.org/10.1016/j.cedpsych.2008.01.003

$\mathrm{Hu}$, D.P., Shi, Z.Y. and Zhou, H. (2009) 'A survey of factors to influence college English autonomous-learning from the perspective of attribution theory', Foreign Languages and Their Teaching, 247, pp.34-37.

Killen, R. (1994) 'Differences between students' and lecturers' perceptions of factors influencing students' academic success at 
university',HigherEducation ResearchandDevelopment, vol.13, no. 2, pp. 199-211. https://doi.org/10.1080/0729436940130210 Lebedina-Manzoni, M. (2004) 'To what students attribute their academic successes and unsuccesses', Education, vol.124, no.4, pp. $699-708$

Lei, C. (2009) 'On causal attribution of academic achievement in college students', Asian Social Science, vol. 5, no. 8, pp. 8796. https://doi.org/10.5539/ass.v5n8p87

Little, A.W. (1985) 'The child's understanding of the cause of academic success and failure: A case study of British school children', British Journal of Educational Psychology, vol. 55, no.1, pp. 11-23. http://dx.doi.org/10.1111/j.2044-8279.1985. tb02601.x

Lu, J., Woodcock, S. and Jiang, H. (2014) 'Investigation of Chinese university students' attributions of English language learning' SAGE Open, October-December 2014, pp. 1-15.

Mao C.-Z. (2003) A study of attribution of English learning for middle school students (Master's thesis). Central China Normal University, Wuhan.

Martinko, M. J. (1995). The nature and function of attribution theory within the organizational sciences. Advances in Attribution Theory: An Organizational Perspective, 7-14. Delray Beach, FL: St. Lucie Press.

McClure, J., Meyer L.H., Garisch, J., Fischer, R., Weir, K.F. and Walkey, F.H. (2011) 'Students' attributions for their best and worst marks: Do they relate to achievement?', Contemporary Educational Psychology, vol. 36, no.2, pp. 71-81. https://doi. org/10.1016/j.cedpsych.2010.11.001

McQuillan, J. (2000) 'Attribution theory and second language acquisition: an empirical analysis', Paper presented at AAAL Conference, Vancouver.

Niles, F. S. (1984) 'Attribution for academic success and failure in Sri Lanka', The journal of Social Psychology, vol. 125, no.3, pp. 401-402. https://doi.org/10.1080/00224545.1985.9922906

O'sullivan, J.T., Howe, M.L. (1996) 'Causal Attributions and Reading Achievement: Individual Differences in Low-Income Families. Causal Attributions and Reading Achievement: Individual Differences in Low-Income Families', Contemporary Educational Psychology, vol. 21, no. 4, pp. 363-87. https://doi. org/10.1006/ceps.1996.0027

Park, Y.S and Kim, U. (1998) 'Locus of control, attributional style, and academic achievement: Comparative analysis of Korean, Korean-Chinese, and Chinese students', Asian Journal of Social Psychology, vol. 1, pp. 191-208. http://dx.doi. org/10.1111/1467-839X.00013

Pintrich, P.R., and Schunk, D.H. (1996) Motivation in education: Theory, research, and applications. Upper Saddle River, NJ: Merrill.

Pishghadam, R. and Zabihi, R. (2011) 'Foreign language attributions and achievement in foreign Language classes' International Journal of Linguistics, vol. 3, no. 1, pp. 1-11. https://doi.org/10.5296/ijl.v3i1.530

Russell, D. (1982) 'The causal dimension scale: A measure of how individuals perceive causes', Journal of Personality and Social Psychology, vol. 42, no. 6, pp. 1137- 1145. http://dx.doi. org/10.1037/0022-3514.42.6.1137

Şahinkarakaş, S. (2011) 'Young Students' Success and Failure Attributions in Language Learning', Social Behavior and Personality, vol. 39, no. 7, pp. 879-886.

Schunk, D.H., Gunn, T.P. (1986) 'Self efficacy and skill development: influence of task strategies and attributions' Journal of Educational Research, vol. 79, no. 4, pp. 238- 244. https://doi.org/10.1080/00220671.1986.10885684
Soric, I. (2009) 'Regulatory Styles, Causal Attributions and Academic Achievement', School Psychology International, vol. 30, no. 4, pp. 403-420. https://doi. org/10.1177/0143034309106946

Stipek, D.J. (1988) Motivation to learn: From theory to practice. 2nd ed. Needham Heights, MA: Allyn and Bacon.

Taşkıran, A. and Aydın, B. (2010) 'EFL learners' causal attributions and dimensionality styles for perceived success and failure', Anadolu University Journal of Social Sciences, vol. 17, no. 2, pp. 11-26.

Tremblay, P.F. and Gardner, R.C. (1995) 'Expanding the motivation construct in language learning', The Modern Language Journal, vol. 79, no. 4, pp. 505-518. http://dx.doi. org/10.1111/j.1540-4781.1995.tb05451.x

Tse, L. (2000) 'Student perceptions of foreign language study: A qualitative analysis of foreign language autobiographies', The Modern Language Journal, vol. 82, no.1, pp. 69-84. http:// dx.doi.org/10.1111/0026-7902.00053

Tulu, G. (2013) 'Boys' and girls' attribution of performance in learning English as a foreign language: The case of Adama high schools in Ethiopia', Educational Research and Reviews, vol. 8, no. 23, pp. 2197-2211. http://dx.doi.org/10.5897/ERR2013.1624 Ushioda, E. (2001) Language learning at university: Exploring the role of motivational thinking. In Z. Dörnyei and R. Schmidt (Eds.), Motivation and second language acquisition (pp. 91124). Honolulu, HI: University of Hawaii Press.

Vallerand, R.J. and Richer, F. (1988) 'On the use of the causal dimension scale in a field setting: A test with confirmatory factor analysis in success and failure situations', Journal of Personality and Social Psychology, vol. 54, no. 4, pp. 704-712. http://dx.doi. org/10.1037/0022-3514.54.4.704

Vispoel, W.P. and Austin, J.R. (1995) 'Success and failure in junior high school: A critical incident approach to understanding students' attributional beliefs', American Educational Research Journal, vol. 32, no.2, pp. 377-412. https://doi. org/10.3102/00028312032002377

Watkins, D. (1985) 'How students explain their academic performance', Higher Education Research and Development, vol. 4, no. 1, pp. 89-93. https://doi.org/10.1080/0729436850040107 Watkins, D. and Regmi, M. (1993) 'Attributing academic success and failure in Nepal', The Journal of Social Psychology, vol. 134, no. 2, pp. 241-242. https://doi.org/10.1080/00224545 .1994 .9711387

Waugh, C.K. (2002) 'Raising self-expectations: The key to motivating students with disabilities', Academic Exchange Quarterly, vol. 6, no. 2, pp.68-73.

Weiner, B. (1979) 'A theory of motivation for some classroom experiences', Journal of Educational Psychology, vol. 71, pp. 3-25. http://dx.doi.org/10.1037/0022-0663.71.1.3

Weiner, B. (1984) Principles for a theory of student motivation and their application within an attributional framework. In R. E. Ames and C. Ames (Eds.), Research on motivation in Education (vol. 1, p. 15-37) Orlando, FL: Academic Press.

Weiner, B. (1985) 'An attributional theory of achievement motivation and emotion', Psychological Review, vol. 92, no.4, pp. 548-573. http://dx.doi.org/10.1037/0033- 295X.92.4.548

Weiner, B. (1986) An Attributional Theory of Motivation and Emotion, New York: Springer Verlag.

Weiner, B. (2000) 'Intrapersonal and interpersonal theories of motivation from an attributional perspective', Educational Psychology Review, vol. 12, no. 1, pp. 18-19. https://doi. org/10.1023/A:1009017532121

Weisz, J.R. and Stipek, D.J. (1982) 'Competence, contingency, 
and the development of perceived control', Human Development, vol. 25 , no. 4, pp. 250- 28. https://doi.org/10.1159/000272812 Williams, M. and Burden, R. (1999) 'Students' developing conceptions of themselves as language learners', Modern Language Journal, vol. 83, no.2, pp. 193-201. https://doi. org/10.1111/0026-7902.00015

Williams, M., Burden, R., Poulet, G. and Maun, I. (2004) 'Learners' perceptions of their successes and failures in foreign language learning', Language Learning Journal, vol. 30, no. 1, pp. 19-29. https://doi.org/10.1080/09571730485200191

Williams, M., Burden, R. and Al-Baharna, S. (2001) Making sense of success and failure: The role of the individual in motivation theory. In Z. Dörnyei and R. Schmidt (Eds.), Motivation and second language acquisition (pp. 171-184). Honolulu: University of Hawaii.

Y1lmaz, C. (2012) 'An investigation into Turkish EFL students' attributions in reading comprehension', Journal of Language Teaching and Research, vol. 3, no. 5, pp. 823- 828. https://doi. org/10.4304/jltr.3.5.823-828

Zeegers, P. (2004) 'Student learning in higher education: A path analysis of academic achievement in science', Higher Education Research and Development, vol. 23, no.1, pp. 35-56. https://doi. org/10.1080/0729436032000168487

Zepke, N., Leach, L. and Butler, P. (2014) 'Student engagement: students' and teachers' perceptions', Higher Education Research and Development, vol. 33, no. 2, pp. 386-398. https://doi.org/10 $.1080 / 07294360.2013 .832160$

\section{Appendix A}

\section{Questionnaire for students}

Dear Student,

Do you find yourself successful in English language learning process? What do YOU think are the reasons for this? Can you fill in the table below by looking at the sample table at the bottom?

\begin{tabular}{|c|c|c|c|c|c|c|c|}
\hline \multirow{2}{*}{\multicolumn{2}{|c|}{$\begin{array}{l}\text { Are you successful in English language learning pro- } \\
\text { cess? } \\
\text { YES } \square \text { NO } \square \\
\text { CAUSES }\end{array}$}} & \multicolumn{2}{|c|}{$\begin{array}{l}\text { Is this situation } \\
\text { caused by you? }\end{array}$} & \multicolumn{2}{|c|}{$\begin{array}{l}\text { Do you think this situa- } \\
\text { tion changes in time? }\end{array}$} & \multicolumn{2}{|c|}{$\begin{array}{l}\text { Can you control this } \\
\text { situation? }\end{array}$} \\
\hline & & YE & NO & YES & NO & YES & NO \\
\hline \multicolumn{8}{|c|}{1.} \\
\hline \multicolumn{8}{|c|}{2.} \\
\hline \multicolumn{8}{|c|}{3.} \\
\hline \multicolumn{8}{|c|}{4.} \\
\hline \multicolumn{8}{|l|}{5.} \\
\hline \multirow{5}{*}{ SAMPLE } & $\begin{array}{l}\text { Are you successful in English lan- } \\
\text { guage learning process? } \\
\text { YES } \square \text { NO }\end{array}$ & \multicolumn{2}{|c|}{$\begin{array}{l}\text { Is this situation caused } \\
\text { by you? }\end{array}$} & \multicolumn{2}{|c|}{$\begin{array}{l}\text { Do you think this situa- } \\
\text { tion changes in time? }\end{array}$} & \multicolumn{2}{|c|}{$\begin{array}{l}\text { Can you control this } \\
\text { situation? }\end{array}$} \\
\hline & CAUSES & YES & $\mathrm{NO}$ & YES & $\mathrm{NO}$ & YES & $\mathrm{NO}$ \\
\hline & I watch films with English subtitles & $\checkmark$ & & & $\checkmark$ & $\checkmark$ & \\
\hline & I revise my notes regularly & $\checkmark$ & & & $\checkmark$ & $\checkmark$ & \\
\hline & I have very good teachers & & $\sqrt{ }$ & $\checkmark$ & & & $\checkmark$ \\
\hline
\end{tabular}

